\title{
Association between the GH receptor/exon 3 genotype and the level of exon 3-positive GH-binding protein in human serum
}

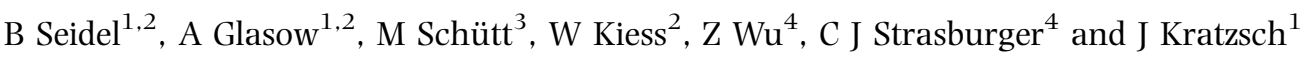 \\ ${ }^{1}$ Institute for Laboratory Medicine, Clinical Chemistry and Molecular Diagnostics, 04103 Leipzig, University of Leipzig, \\ ${ }^{2}$ Children's Hospital, University of Leipzig, ${ }^{3}$ Department of Internal Medicine 1, 23538 Lübeck, Medical University of Lübeck and \\ ${ }^{4}$ Medizinische Klinik Innenstadt der Universität, 80336 Munich, LMU Munich, Germany \\ (Correspondence should be addressed to J Kratzsch, Institute for Laboratory Medicine, Clinical Chemistry and Molecular Diagnostics, O4317 Leipzig, \\ University of Leipzig, Liebigstrasse 27,D-04103 Leipzig, Germany; Email: kraj@medizin.uni-leipzig.de)
}

\begin{abstract}
Objective: The human GH-binding protein (GHBP) is derived from the GH receptor (GHR) through proteolytic cleavage of its extracellular domain. Two isoforms of the GHBP exist, differing in the retention or exclusion of exon 3: E3(+)GHBP and E3(-)GHBP. Our study aimed to answer the questions whether the level of E3(+)GHBP in the serum correlates with the GHR exon 3 expression and whether or not the E3 genotype matches the mRNA expression pattern.

Methods: Since exon 3 retention/deletion can be detected at the protein level using epitope-specific antibodies, we were able to quantify the two isoforms by means of specific immunoassays in a total of 37 individuals. Additionally, these persons were also genotyped for exon 3 by genomic PCR and tested for GHR exon 3 mRNA expression by RT-PCR.

Results: We found a significant correlation between GHR exon 3 genotype and the ratio of E3(+)GHBP and E3 $(-)$ GHBP in the serum. Moreover, the genotype matched exactly the mRNA expression in fibroblasts and/or blood leukocytes in all samples investigated. The levels of E3(+)GHBP are more strongly correlated with body mass index, proinsulin and C-peptide than the levels of the E3(-) isoform.

Conclusions: Our results show that the GHR exon 3 genotype is in accord with the type of GHBP isoforms found in the serum. Our data thus support the idea that the presence of exon 3-retaining and -excluding GHR/GHBP isoforms results from a genomic deletion rather than from alternative splicing.
\end{abstract}

European Journal of Endocrinology 148 317-324

\section{Introduction}

The human pituitary-derived growth hormone (GH) exerts a variety of somatotropic and metabolic effects mediated through interaction with its cognate highaffinity receptor (1). The integral membrane protein GHR (GH receptor) is part of the cytokine receptor superfamily (2) and consists of an extracellular ligand-binding domain, a single membrane-spanning domain and an intracellular part, which conveys the signal, after dimerization, via activation of JAK-STAT and MAPK pathways (3). The extracellular domain of the GHR is also found as a soluble form in the blood and referred to as GH-binding protein (GHBP) (4). The origin of the GHBP differs amongst species: in mice and rats, an alternatively spliced $1.5 \mathrm{~kb}$ transcript coding for GHBP exists $(5,6)$, whereas in man and rabbit the GHBP is assumed to originate exclusively from proteolytic cleavage of the membrane-bound GHR by as yet unknown mechanisms (7). There are indications that the action of the metalloprotease TACE (tumor necrosis factor- $\alpha$-converting enzyme) might be responsible for this cleavage (8) and that the process of shedding is mediated by activation of protein kinase $\mathrm{C}(9)$.

With respect to the extracellular domain-encoding region of the GHR mRNA, two isoforms have been described which differ in the retention or exclusion of exon 3, the E3(+)GHR and the E3(-)GHR respectively (10), the latter resulting in a polypeptide lacking 22 amino acids close to the N-terminus. In preceding publications, these isoforms were considered as a consequence of alternative splicing, either tissue-specific $(10,11)$, developmentally regulated (12), speciesspecific (13) or individual-specific $(12,14)$. In contrast, evidence was provided that the exon 3-negative isoform results from a retro-element, which causes a genomic $2.7 \mathrm{~kb}$ deletion including exon 3 (15). As a result of these new data, the Mendelian mode by which this trait is inherited as well as the deletion of nonconsecutive 
exons in patients with Laron syndrome is now easily conceivable. On the other hand, the described amplification of exon 3 from genomic DNA of individuals expressing no E3(+)GHR transcripts $(12,16)$ remains in contradiction to a genomic deletion event.

The physiological function of the GHBP is not yet completely understood. However, it has been shown that when the binding protein is associated with $\mathrm{GH}$, it can elevate the growth-promoting effect of the hormone (17), presumably by prolongation of its halflife (18).

As far as ligand specificity, ligand affinity and the general ability to shed GHBP are concerned $(11,19$, 20), the typical biological properties of E3(-)GHR do not differ from the full-length GHR. However, the possibility that the missing amino acids affect signal transduction properties of the receptor cannot be ruled out and remains to be examined (21). Furthermore, most recently the possibility that different shedding properties of the receptor exist, depending on the isoform, was hypothesized (22).

Due to the codominant expression of the alleles in heterozygous individuals, both isoforms can be detected at the transcriptional as well as at the protein level. We recently demonstrated that both $\mathrm{E} 3(+) \mathrm{GHBP}$ and E3 $(-)$ GHBP could be quantified in the serum by means of newly developed isoform-specific immunoassays (23). It was shown that both molecular species do not show any correlation with each other, and that E3(+)GHBP appeared to have a stronger correlation with indicators and metabolic risk factors of adiposity than E3(-)GHBP, which might point towards differences in their functional properties.

The objectives of the present study were, first, to study the association of the exon 3 genotypes (i.e. the presence of $\mathrm{E} 3(+)$ and/or $\mathrm{E} 3(-)$ alleles) with the levels of GHBP isoforms in the periphery. Secondly, we wanted to relate the GHR exon 3 genotype to the E3(+) and/or E3 $(-)$ GHR mRNA expression in skin fibroblast cultures and/or leukocytes. Thirdly, we were interested in looking for putative correlations between the GHR exon 3 genotype and clinical parameters of the individuals under investigation.

\section{Materials and methods}

\section{Cell culture procedures and materials}

Fibroblast cultures were derived after outgrowth from human skin biopsies and cultured in $30 \mathrm{ml}$ Dulbecco's modified Eagle's medium/nutrient mix F12 containing $15 \mathrm{mmol} / \mathrm{l}$ Hepes and L-glutamine (Life Technologies, Eggenstein, Germany) supplemented with $10 \%$ fetal calf serum (Biochrom KG, Berlin, Germany), 2 mmol/l L-glutamine (Life Technologies), 100 units $/ \mathrm{ml}$ penicillin, $0.1 \mathrm{mg} / \mathrm{ml}$ streptomycin and $0.25 \mu \mathrm{g} / \mathrm{ml}$ amphotericin (Sigma-Aldrich, Steinheim, Germany) in $175 \mathrm{ml}$ tissue culture flasks (Becton Dickinson, Meylan Cedey,
France). Medium was replaced every $72 \mathrm{~h}$. For passaging, cells were detached by $0.05 \%$ trypsin and $0.02 \%$ EDTA. The DNA-binding dye Hoechst 33342 (Bisbenzamid-Fluorochrom; Hoechst AG, Frankfurt, Germany) was used to prove the absence of mycoplasma contamination.

PBMNCs (peripheral blood mononuclear cells) were isolated by conventional Ficoll-Paque density gradient centrifugation, washed three times with sterile PBS and subjected to RNA preparation as described below.

If not otherwise indicated, chemicals were obtained from Sigma-Aldrich or Merck (Darmstadt, Germany), and molecular biology reagents from Roche Diagnostics GmbH (Mannheim, Germany).

\section{Individuals}

For the genotyping experiments, a total of 46 subjects (25 females and 21 males, age range 16-70 years, BMI (body mass index) median $26.0 \mathrm{~kg} / \mathrm{m}^{2}$, quartile range $23.7-31.3 \mathrm{~kg} / \mathrm{m}^{2}$ ) were included in our study as listed in Table 1 . The majority of them (nos 1-37 in Table 1) were patients of the Biomed 2 project (BMH-CT96-0751, European Union, Brussels, Belgium) (24). This group included individuals of five families with a known history of type 2 diabetes: five patients were treated with insulin, three patients were treated with oral antidiabetes drugs and the remaining individuals showed normal results in the oral glucose tolerance test. An additional group of nine unrelated healthy persons (University of Leipzig, Germany) were included in our analysis. For correlation analysis between genotype and E3(+)GHBP, data of 37 subjects were applied, as sera from nine subjects were unobtainable (see Table 1). For the comparison between mRNA expression and genotype, all subjects with existing fibroblast cultures were considered $(n=37$, see Table 1). For correlation with clinical parameters, 25 individuals from the Biomed 2 project were included as indexed in Table 1. Fibroblast cell cultures and sera were kindly provided by Prof. Dr H Klein and Dr M Schuett, Medical University of Lübeck, Clinic I, Germany, and by Prof. F Beguinot, Department of Biology, Cellular Biology and Molecular Pathology, University of Naples, Italy, or derived from patients at the Children's Hospital, University of Leipzig. The study was approved by the local ethical committees of the University of Leipzig, University of Lübeck and University of Naples.

\section{Molecular biological techniques}

Total RNA was isolated from fibroblast cultures (grown to confluence in $75 \mathrm{ml}$ flasks) and/or from PBMNCs using RNAeasy mini-columns (Qiagen, Hilden, Germany). Genomic DNA was then digested with RNAse-free DNAse (Qiagen) following the original protocol. For RT (reverse transcription) first-strand synthesis, the $10 \mu \mathrm{l}$ 
Table 1 mRNA expression of GHR isoforms in fibroblast cultures, genotype and exon 3-related GHBP quantification data obtained from 46 individuals.

\begin{tabular}{|c|c|c|c|c|c|c|c|}
\hline Subject no. & $\begin{array}{c}\text { RT-PCR } \\
\text { GHR exon } 3\end{array}$ & $\begin{array}{c}\text { Genomic } \\
\text { PCR exon } 3\end{array}$ & $\begin{array}{l}\text { Total GHBP } \\
(\mathrm{pmol} / \mathrm{l})\end{array}$ & $\begin{array}{c}\text { E3(+)GHBP } \\
(\mathrm{pmol} / \mathrm{l})\end{array}$ & $\begin{array}{c}\text { E3(+)GHBP } \\
(\% \text { of total GHBP) }\end{array}$ & Age & Gender \\
\hline 1 & + & + & 303 & 158 & 52 & 70 & Male \\
\hline 2 & + & + & 755 & 397 & 53 & 61 & Male \\
\hline 3 & $=$ & $=$ & 1720 & 1334 & 78 & 17 & Female \\
\hline 4 & $=$ & $=$ & 1247 & 229 & 18 & 16 & Male \\
\hline $5^{*}$ & $=$ & $=$ & 918 & 408 & 44 & 33 & Female \\
\hline $6^{*}$ & $=$ & $=$ & 394 & 193 & 49 & 23 & Male \\
\hline $7^{*}$ & $=$ & $=$ & 977 & 473 & 48 & 29 & Male \\
\hline $8^{*}$ & + & + & 1507 & 1430 & 95 & 27 & Female \\
\hline $9^{*}$ & $=$ & $=$ & 580 & 291 & 50 & 32 & Male \\
\hline $10^{*}$ & - & - & 300 & 0 & 0 & 38 & Female \\
\hline $11^{*}$ & - & - & 573 & 0 & 0 & 44 & Male \\
\hline $12^{*}$ & $=$ & $=$ & 1428 & 539 & 38 & 45 & Female \\
\hline $13^{*}$ & $=$ & $=$ & 1464 & 561 & 38 & 45 & Female \\
\hline $14^{*}$ & $=$ & $=$ & 555 & 247 & 45 & 40 & Female \\
\hline $15^{\star}$ & $=$ & $=$ & 1016 & 466 & 46 & 42 & Female \\
\hline 16 & + & + & /I & $/ /$ & /I & 57 & Female \\
\hline 17 & $=$ & $=$ & /I & // & $/ 1$ & 68 & Female \\
\hline 18 & $=$ & $=$ & // & // & // & 46 & Male \\
\hline 19 & $=$ & $=$ & /I & /I & // & 39 & Male \\
\hline 20 & $=$ & $=$ & /I & // & // & 48 & Male \\
\hline $21^{*}$ & - & - & 457 & 0 & 0 & 56 & Male \\
\hline $22^{*}$ & $=$ & $=$ & 1160 & 499 & 43 & 55 & Female \\
\hline 23 & + & + & // & // & // & 60 & Male \\
\hline 24 & $=$ & $=$ & // & // & // & 40 & Female \\
\hline $25^{\star}$ & + & + & 1047 & 534 & 51 & 56 & Female \\
\hline $26^{*}$ & + & + & 792 & 671 & 85 & 64 & Female \\
\hline 27 & + & + & $/ 1$ & /I & /I & 27 & Female \\
\hline $28^{*}$ & + & + & 1450 & 951 & 66 & 58 & Male \\
\hline $29^{*}$ & $=$ & $=$ & 914 & 452 & 49 & 47 & Male \\
\hline $30^{*}$ & $=$ & $=$ & 443 & 223 & 50 & 67 & Male \\
\hline $31^{*}$ & $=$ & $=$ & 375 & 199 & 53 & 64 & Female \\
\hline $32^{*}$ & $=$ & $=$ & 349 & 151 & 43 & 53 & Male \\
\hline $33^{*}$ & + & + & 1163 & 795 & 68 & 50 & Female \\
\hline $34^{*}$ & + & + & 1697 & 1113 & 66 & 47 & Male \\
\hline $35^{\star}$ & + & + & 2702 & 1483 & 55 & 25 & Female \\
\hline $36^{*}$ & + & + & 1754 & 1156 & 66 & 23 & Female \\
\hline $37^{*}$ & I & $t^{\mathrm{b}}$ & 1622 & 1069 & 66 & 49 & Female \\
\hline 38 & 1 & $t^{\mathrm{b}}$ & 243 & 219 & 90 & 44 & Male \\
\hline 39 & 1 & $t^{\mathrm{b}}$ & 274 & 276 & 100 & 45 & Male \\
\hline 40 & 1 & $-b$ & 392 & 17 & 4 & 57 & Female \\
\hline 41 & 1 & $--^{b}$ & 728 & 0 & 0 & 37 & Female \\
\hline 42 & 1 & $t^{\mathrm{b}}$ & 210 & 163 & 78 & 52 & Female \\
\hline 43 & 1 & $={ }^{\mathrm{b}}$ & 370 & 123 & 33 & 56 & Female \\
\hline 44 & 1 & $=\mathrm{b}$ & 1212 & 338 & 28 & 49 & Female \\
\hline 45 & I & $t^{\mathrm{b}}$ & 303 & 274 & 90 & 54 & Male \\
\hline 46 & $=$ & $={ }^{b}$ & // & $/ /$ & /I & 43 & Male \\
\hline
\end{tabular}

+ homozygous positive $\mathrm{E} 3(+/+)$; = heterozygous $\mathrm{E} 3(+/-)$; - homozygous negative $\mathrm{E} 3(-/-)$; / no fibroblasts available; // no serum available; ${ }^{b}$ genomic DNA prepared from white blood cells.

* data of these individuals were used for the correlations shown in Fig. 3.

reaction mix, containing $1 \mu \mathrm{g}$ RNA, $1 \times \mathrm{RT}$ buffer, $200 \mu \mathrm{mol} / \mathrm{l}$ dNTPs, $200 \mathrm{ng}$ random hexamer primers and $0.01 \mathrm{~mol} / \mathrm{l}$ dithiothreitol was denatured at $65^{\circ} \mathrm{C}$ for $5 \mathrm{~min}$ and then chilled on ice for $2 \mathrm{~min}$. After adding $200 \mathrm{U}$ MMLV (Moloney murine leukemia virus reverse transcriptase) (Life Technologies) together with $40 \mathrm{U}$ RNAse inhibitor (Roche Diagnostics) the reaction was performed at $39^{\circ} \mathrm{C}$ for $60 \mathrm{~min}$ and terminated by denaturation at $94^{\circ} \mathrm{C}$ for $2 \mathrm{~min}$. For negative controls, the enzyme was omitted. The quality of each template was confirmed by control PCR for glyceraldehyde 3'-phosphate dehydrogenase (25).

PCR was performed in a thermal cycler (GeneAmpPCRsystem 2400; Perkin Elmer, Uberlingen, Germany) using the Expand high fidelity system (Roche Diagnostics). Primer sequences for the differentiation between E3(+)GHR and E3(-)GHR transcripts were derived from accession number NM000163 (1) nucleotides 59-81 (5'-CTGCTGTTGACCTTGGCACTGGC-3'; forward primer, exon 2) and nucleotides 415-393 (5'-AGGTATCCAGATGGAGGTAAACG-3'; 
reverse primer, exon 4). PCR amplification conditions were $3 \mathrm{~min}$ initial denaturation at $94^{\circ} \mathrm{C}$, followed by 35 cycles of denaturation at $94^{\circ} \mathrm{C}$ for $30 \mathrm{~s}$, primer annealing at $60^{\circ} \mathrm{C}$ for $30 \mathrm{~s}$ and elongation at $72^{\circ} \mathrm{C}$ for $40 \mathrm{~s}$, with a final elongation at $72^{\circ} \mathrm{C}$ for another $7 \mathrm{~min}$. This results in PCR products of $360 \mathrm{bp}$ length for exon 3-retaining and/or of $294 \mathrm{bp}$ length for the exon 3-deleted form respectively.

In all PCR experiments amplification in the absence of cDNA was performed as a negative control. PCR products were run in a $1.5 \%$ agarose gel containing ethidium bromide and their size was estimated from comparison with a 100 bp ladder (Life Technologies).

For genomic PCR, DNA was extracted from cultured skin fibroblasts or, when fibroblasts were not available, from total EDTA-blood using a commercial DNA purification kit (Wizard; Promega, Madison, WI, USA) and $100 \mathrm{ng}$ were subjected to a multiplex PCR analysis. The forward primer G1 (5'-TGTGCTGGTCTGTTGGTCTG-3', GenBank accession number AF155912, nucleotides 3285-3304) and the reverse primers G2 (5'-AGTCGTTCCTGGGACAGAGA-3', nucleotides 65346515) and G3 (5'-CCTGGATTAACACTTTGCAGACTC-3', nucleotides 4219-4196) were used to amplify exon 3-positive $(935 \mathrm{bp})$ and/or exon 3-negative PCR (532 bp) products applying exactly the same PCR settings as described by the authors (15). In some cases, when the results were inconclusive (heterozygous individuals), the PCR was repeated with the reverse primers given separately, because the synthesis was always in favor of the shorter PCR product (532 bp). Agarose gel electrophoresis was performed as described above.

\section{Biochemical parameters}

E3(+)GHBP and total GHBP in human serum were determined by immunoassays in microtiter plates as recently described (26). Briefly, the principle for the measurement of both parameters, total GHBP and E3(+)GHBP alone, was the use of specific antibodies. In the case of total GHBP, the absorbed first antibody binds GHBP outside the human $\mathrm{GH}$ (hGH) binding site and the second detecting antibody binds GHBP within the hGH binding site. The same first antibody was used for the measurement of E3(+)GHBP alone; additionally, an anti-peptide antibody against E3(+)GHBP was acting to detect specifically this isoform. Both assays were based on the same preparation of recombinant GHBP as standard. Intra- as well as interassay coefficients of variation were below $11 \%$ for both methods. Serum levels of E3(-)GHBP were calculated by the difference between total GHBP and E3(+)GHBP. Serum levels of proinsulin (DRG International, Mountainside, NJ, USA; sensitivity $0.5 \mathrm{pmol} / \mathrm{l}$ ), insulin and C-peptide (Dako Ltd, Cambridge, UK; sensitivity $2.0 \mu \mathrm{IU} / \mathrm{l}$ and $0.2 \mathrm{ng} / \mathrm{ml}$ ) were determined by ELISAs. Intra-assay and interassay coefficients of variation for these three assays were below $10 \%$ in our hands.

\section{Statistics}

The data were found to be non-normally distributed and therefore methods of nonparametric statistics (Spearman's coefficient of variation and the MannWhitney U-test) were used to calculate the significance of our results.

All statistics were performed with the Statistica Program (Statsoft Inc., Tulsa, OK, USA).

\section{Results}

As seen from Table 1, the genotyping experiments for GHR revealed that out of a total of 46 individuals there were 18 homozygous positives (E3(+)GHR), 23 were heterozygous and five were genotyped as homozygous negatives $(\mathrm{E} 3(-) \mathrm{GHR})$ thus resulting in a ratio of $39 \%: 50 \%: 11 \%$. These values deviate from those that can be expected from the Hardy-Weinberg law as a result of partial family relationships within the group under investigation. However, the tendency towards a substantially lower frequency of the E3(-) allele is apparent.

The measurements of GHBP isoform protein expression as determined by two independent specific immunoassays suggests that, in terms of the ratio between E3(+)GHBP and total GHBP, a substantial dependence on the GHR E3 genotype exists, as seen in Fig. 1. The mean values \pm S.E.M. for the particular genotypes were: $72.07 \pm 4.26$ for $\mathrm{E} 3(+/+), 44.26 \pm 3.04$ for

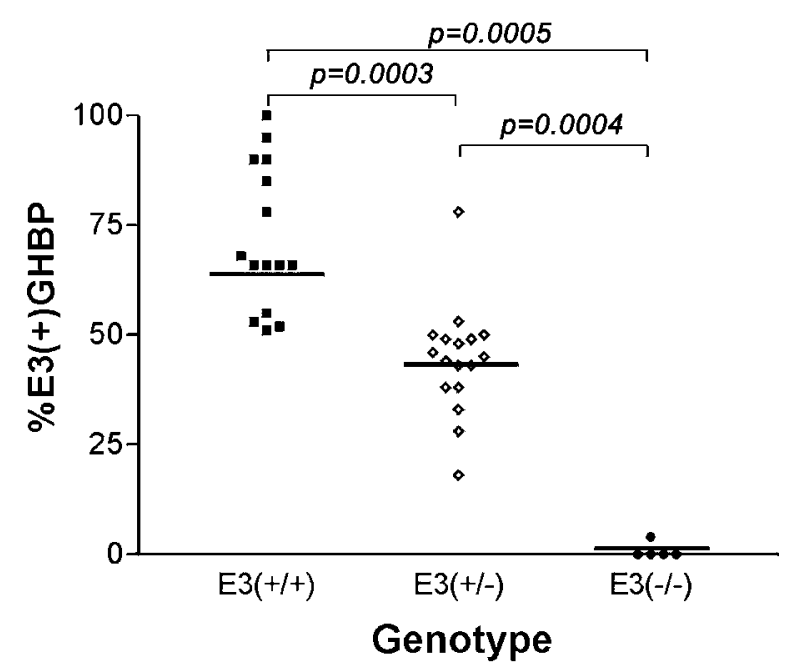

Figure 1 The graph displays the correlation between E3-GHR genotype and the amount of E3(+)GHBP in the serum given as the percentage of exon 3 immunoreactivity in relation to total GHBP immunoreactivity. Total and E3(+)GHBP were measured by means of specific immunoassays, and the genotype was determined by genomic PCR: $n=15$ for E3(+/+), $n=17$ for $\mathrm{E} 3(+/-), n=5$ for $\mathrm{E} 3(-/-)$. Significance levels were calculated using the Mann-Whitney U-test; horizontal bars represent the median for each genotype. Note that the percentage differs from the expected $100 \%$ for homozygous exon 3-retaining individuals; this discrepancy is addressed in the Discussion section. 
$\mathrm{E} 3(+/-)$ and $0.8 \pm 0.8$ for $\mathrm{E} 3(-/-)$. However, the genotype is not absolutely predictable from the level of E3(+)GHBP in plasma since there is a partial overlap in the levels from homozygous positive and heterozygous individuals (Fig. 1). This might indicate that the shedding of the GHBP isoforms is probably, to a certain degree, modified by individual genetic traits independently of the genotype. This is particularly evident in the case of the heterozygous individuals where the percentage of E3(+) differs in a range between 18 and $78 \%$. Likewise, the values for the homozygous positives can be as low as $51 \%$, deviating from the expected value of $100 \%$, which is reached in one case only.

To address the question whether E3(+)GHR-specific PCR products can be amplified from genomic DNA of individuals who do not express exon 3 mRNA, we compared RT-PCR results with those derived from genomic PCR (Fig. 2). It can be clearly seen that there is a perfect match of cDNA and genomic DNA in the 37 samples investigated, which is independent of the source of RNA for RT-PCR (skin fibroblasts, PBMNCs). Furthermore, in all three cases where no exon 3 transcripts could be detected by RT-PCR (nos 10, 11 and 21), no genomic PCR product for exon 3 could be amplified either.

Additionally, our results from another preliminary expression study of exon 3 isoforms in two different tissues from the same heterozygous individual (skin biopsy fibroblast cultures vs PBMNCs) display no differences in the mRNA expression patterns (data not shown). The abundance of the GHR transcript in blood cells, however, appeared considerably lower than in fibroblast cultures.

Furthermore, correlation of E3(+)GHBP and E3(-)GHBP expression with several clinical parameters was investigated. Levels of both isoforms of GHBP are strongly related to total GHBP levels. However, the correlation between serum levels of total GHBP and E3(+)GHBP $(r=0.87, P<0.0001)$ was significantly $(P<0.05)$ stronger than the relationship between total GHBP and E3 $(-)$ GHBP $(r=0.71, P<0.0001)$. Interestingly, the serum concentration of E3(+)GHBP did not correlate with E3(-)GHBP levels $(r=0.28$, $P=0.10)$. Moreover, the relationships between the individual concentrations of both, E3(+) and E3(-), isoforms and BMI $(r=0.54, P<0.0005$ vs $r=0.38$, $P=0.02)$ as well as fasting proinsulin $(r=0.69$, $P<0.0001$ vs $r=0.19, P=0.36$; Fig. 3), insulin $(r=0.60, P=0.001$ vs $r=0.20, P=0.34)$ and $C$ peptide $(r=0.48, P=0.015$ vs $r=0.26, P=0.20)$ were also quite different. The ratio of $\mathrm{E} 3(+) \mathrm{GHBP}$ related to total GHBP demonstrated significant correlations with BMI $(r=0.40, P<0.05)$ as well as with proinsulin $(r=0.60, P<0.01)$ and insulin $(r=0.58, P=0.003)$.

\section{Discussion}

We have analyzed, for the first time, the GHR exon 3 genotypes in parallel with the respective GHR mRNA expression in fibroblast cultures and related the results
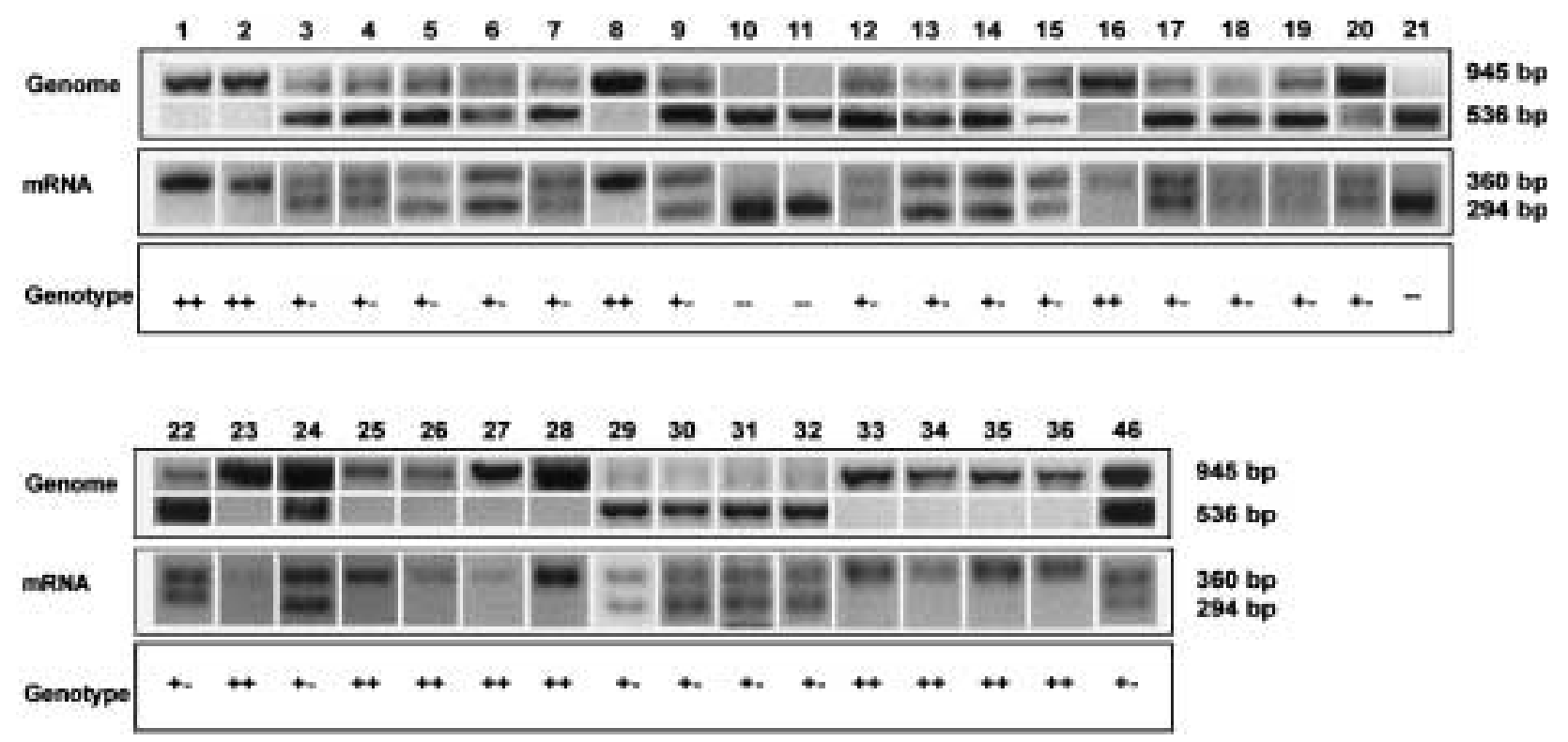

Figure 2 Comparison of genotype and E3-GHR isoform-specific mRNA expression in cultured human skin fibroblasts ( $n=37$ ); DNA and total cell RNA were prepared from fibroblasts grown in vitro. Genomic PCR and RT-PCR for detection of E3-GHR isoform-specific DNA sequences were done as described in the Materials and methods section using the respective primer pairs (numbering according to Table 1). Note that strict matching for genotype and mRNA expression was found in all cases. (For nos 37-45 only genomic DNA samples were available, so they are not shown herein.) 

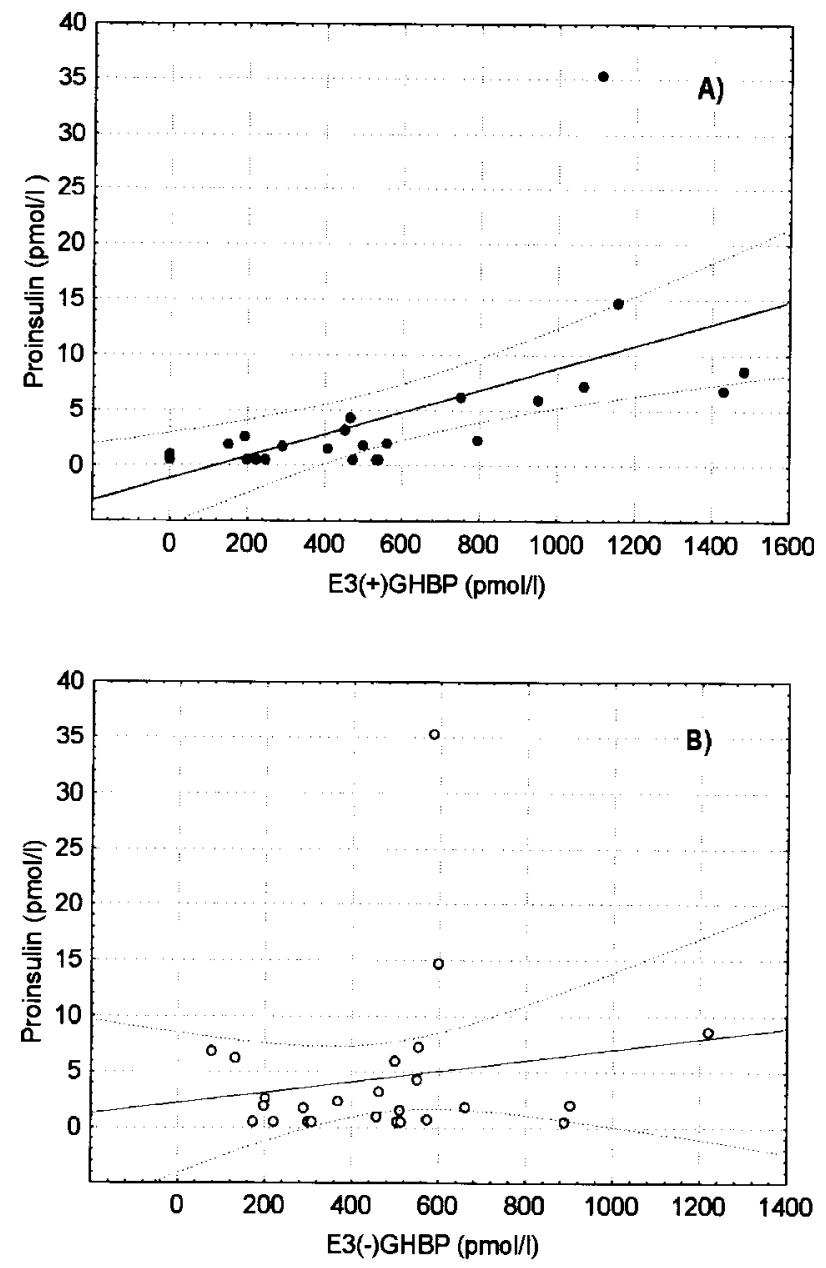

Figure 3 Comparison between serum levels of proinsulin and both isoforms of GHBP ((A) E3(+)GHBP, $r=0.69, P<0.0001$; (B) E3(-)GHBP, $r=0.19, P=0.36)$ ) of patients with type 2 diabetes mellitus, treated with insulin $(n=5)$ or oral antidiabetes drugs $(n=3)$, and of their relatives who showed normal results in the oral glucose tolerance test $(n=17)$. The figure includes the linear regression line with $95 \%$ confidence limits. Removal of the obvious outliers from Spearman's rank correlation reduces the $r$ values only slightly to $r=0.65, P=0.0006$ for E3(+)GHBP, and to $r=0.13, P=0.56$ for $\mathrm{E} 3(-) \mathrm{GHBP}$.

to the levels of GHBP exon 3 isoforms as measured in the serum.

The distribution of the E3(+)GHR and E3(-)GHR genotypes in the general population was shown to reflect the allele frequencies of 75 and $25 \%$ respectively (15), following the Hardy-Weinberg equilibrium (27). Our data for the genotypes of GHR exon 3 differ from these allele frequencies due to the fact that we were evaluating a smaller $(n=46)$ and partly related population in which the preconditions of the HardyWeinberg law are not met.

As we could show previously (23), the exon 3-related heterogeneity of the receptor is reflected at the binding protein level as well, which is understandable considering the origin of human GHBP by shedding from the membrane-bound GHR molecule.

Our data provide evidence that the GHBP isoforms found in the serum are substantially correlated with the GHR exon 3 genotype thus suggesting a gene-dosage effect for the exon 3-positive allele. This genotype is not absolutely predictable from the immunoassay data since there is a partial overlap between the values for homozygous E3(+)GHR and heterozygous E3(+)/E3(-)GHR, whereas the homozygous negative genotype is very clearly mirrored in the almost exclusive abundance of E3(-)GHBP. This issue might be explained as follows. Since the two immunoassays have comparable low intra- and interassay coefficients of variation, other issues than the genotype only could account for this phenomenon. These issues may include a different state of GH/GHBP complex formation as well as binding of GHBP to other proteins such as alpha 2-macroglobulin (28), which might mask exon 3 epitopes and thereby diminish the immunoassay values for E3(+)GHBP. The given interindividual variability of these conformational factors could result in a partial underestimation of exon 3 in antibody-based assays. Moreover, the possibility that - independently from the genotype - skipping of exon 3 by alternative splicing may occur to a certain degree in homozygous positives cannot be fully excluded. This may happen in the liver as the major source of GHBP, but also in adipose tissue and skeletal muscle, which are hypothesized to contribute to GHBP levels as well $(29,30)$. Nevertheless, the resulting deviations do not conceal the substantial differences between positive homozygous and heterozygous individuals in E3(+)GHBP expression.

Our previous findings pointed to a considerably stronger correlation of E3(+)GHBP with anthropometric parameters such as BMI, fat mass or waist circumference and the metabolic risk factors of adiposity fasting insulin, uric acid, triglycerides, apolipoprotein B levels or diastolic blood pressure than E3(-)GHBP, which could indicate functional differences (23). We extended these investigations to a broader basis of subjects and to other parameters such as fasting proinsulin and C-peptide levels, which are of particular relevance for adipositas. The results presented here substantially support our preliminary findings. Moreover, fasting proinsulin, insulin and C-peptide levels and again BMI values were more strongly related to the $\mathrm{E} 3(+) \mathrm{GHBP}$ than to the E3(-)GHBP isoform. Also, an augmented ratio of $\mathrm{E} 3(+) \mathrm{GHBP}$ related to total GHBP is paralleled by increased serum levels of proinsulin and insulin. These findings and the fact that both GHBP variants do not correlate with each other are in keeping with our hypothesis about a functional difference for the two isoforms. On the other hand, a different regulation of the shedding mechanism of the receptor's extracellular domain in the presence or absence of the exon 3 may occur. Interestingly, Conte et al. (22) found in COS-7 cells transfected with the two different isoforms 
that the number of binding sites in the supernatant of E3(-)GHR cells was lower compared with the E3(+)GHR cells. It is indeed conceivable that the missing 22 amino acids in the extracellular domain renders the molecule less prone to proteolysis by the respective enzymes, possibly by changing the three-dimensional conformation. Zhang et al. (8) assume that a molecular conformation rather than a linear sequence might represent the target for the putative cleavage enzyme TACE, since there is no clear consensus sequence for TACE amongst its known substrate proteins.

Whereas no meaningful differences in the biological properties between the two isoforms have been discovered until now $(10,11,20)$, a change in the conformation of the receptor complex due to different combinations of its monomeric constituents may influence downstream signaling after binding of the ligand (12). The missing 22 amino acids in the extracellular part of the E3(-)GHR isoform that are encoded by exon 3 do not harbor any significant motifs for phosphorylation or glycosylation as found by searching the PROSITE database (http://www.ebi.ac.uk/ ppsearch/). However, the transformation of the original asparagine into an aspartate residue at the junction between exon 2 and 4 causes the loss of an asparagine-mediated N-glycosylation site, which might have consequences for the glycosylation of the extracellular part of the receptor.

The origin of the E3(-)GHR isoform was formerly considered as a consequence of an unusual RNA splicing event that is regulated individually, which originates from a polymorphism in the human GHR gene and was inherited following a Mendelian trait (16). Other authors have also confirmed the individualspecific expression of the GHR as well $(12,14)$. Recently, Pantel et al. (15) have published data from analysis of a $6.8 \mathrm{~kb}$ fragment of the human GHR gene spanning exon 3. Surprisingly, the authors found that in individuals with no exon 3 expression, a $2.7 \mathrm{~kb}$ genomic deletion involving the complete exon 3 sequence is present. The authors demonstrated that this is the result of a retroviral insertion event that had happened 25 million years ago, with subsequent partial duplication of the retrovirus sequence, and eventually the deletion of the DNA between the two retro-elements during primate evolution. Although the data for this 'retrovirus-mediated alternative splice mimicry' are quite convincing, some uncertainties still exist. First, the fact that the exon 3 deletion has already been shown to exist in rhesus monkeys (31) is contradictory to the proposed lineage of retro-elements at the GHR exon 3 locus during primate evolution, in which the deletion is stated not to occur before the divergence of Pongina and Hominina subtribes (15). More importantly, two groups demonstrated amplification of E3(+) genomic DNA from individuals only expressing the E3(-)GHR transcripts, which is inconsistent with the genomic deletion theory $(12,16)$. With regard to this point, in our genomic PCR experiments, we could in no case amplify genomic GHR exon 3 sequences from DNA of patients expressing the E3(-)GHR mRNA exclusively.

Pantel et al. (15) found a perfect correlation between the genotype and the mRNA expression pattern of exon 3 isoforms $(n=11)$. We were able to confirm this consistency in a population sample three times as large $(n=37)$ compared with this cohort, which is in keeping with the genomic deletion theory. This is also supported by our preliminary results, showing no tissue-specific exon 3 mRNA expression pattern. The much lower abundance of GHR mRNA in leukocytes compared with fibroblasts is mainly attributable to B lymphocytes (32). The tissue-dependence of the exon 3 isoform expression confirmed previously $(10,11)$ might actually reflect individual-specific rather than tissue-specific expression. On the one hand, placental tissue RNA preparations contain transcripts of both maternal and fetal origin, and on the other hand, the tissues may be obtained from different individuals (reviewed in (21)).

Taken together our data indicate that a strong correlation between the E3-GHR genotype and the level of E3-GHBP immunoreactivity in the serum exists. Also, an identical match between the genotype and the transcriptional expression pattern of exon 3 isoforms could be shown. Both of these results are more consistent with the hypothesis of a genotype-derived exon 3 phenotype. Furthermore, our findings about the stronger correlation of $\mathrm{E} 3(+) \mathrm{GHBP}$ with metabolic risk factors of adiposity, compared with E3(-)GHBP, could be a clue for a putative different functionality of the GHR/GHBP isoforms. To support this hypothesis, further studies are mandatory, in particular to prove the more speculative ideas about a different shedding capacity of the receptors. It should also be of considerable interest to analyze whether the downstream signaling pathways are altered by conformational changes within the receptor molecule as a result of different E3(+)/E3(- ) dimer combinations which constitute the functional GHR. Finally, from a technical point of view, it would be beneficial to develop a direct immunoassay based on neo-epitopes deriving from the exon 2 /exon 4 junction, in order to circumvent methodological problems.

\section{Acknowledgements}

This work was supported by the Bundesministerium für Bildung und Forschung, Interdisciplinary Center for Clinical Research, University of Leipzig (01KS9504; Project B15) as well as by a grant from the Eli Lilly \& Co. International Foundation. The authors are very grateful to Mrs A Berthold for excellent technical assistance, and to A Böttner and J Klammt for many fruitful discussions. The authors also wish to thank Prof. H H Klein 
(Lübeck, Germany) and Prof. F Beguinot (Naples, Italy) for their support.

\section{References}

1 Leung DW, Spencer SA, Cachianes G, Hammonds RG, Collins C, Henzel WJ et al. Growth hormone receptor and serum binding protein: purification, cloning and expression. Nature 1987330 537-543.

2 Bazan JF. Structural design and molecular evolution of a cytokine receptor superfamily. PNAS 199087 6934-6938.

3 Postel-Vinay MC \& Kelly PA. Growth hormone receptor signalling. Baillière's Best Practice and Research in Clinical Endocrinology and Metabolism $199610323-336$.

4 Baumann G, Stolar MW, Amburn K, Barsano CP \& DeVries BC. A specific growth hormone-binding protein in human plasma: initial characterization. Journal of Clinical Endocrinology and Metabolism $1986 \mathbf{6 2} 134-141$.

5 Baumbach WR, Horner DL \& Logan JS. The growth hormonebinding protein in rat serum is an alternatively spliced form of the rat growth hormone receptor. Genes and Development 1989 3 1199-1205.

6 Smith WC, Kuniyoshi J \& Talamantes F. Mouse serum growth hormone $(\mathrm{GH})$ binding protein has $\mathrm{GH}$ receptor extracellular and substituted transmembrane domains. Molecular Endocrinology 19893 984-990.

7 Sotiropoulos A, Goujon L, Simonin G, Kelly PA, Postel-Vinay MC \& Finidori J. Evidence for generation of the growth hormonebinding protein through proteolysis of the growth hormone membrane receptor. Endocrinology 1993132 1863-1865.

8 Zhang Y, Jiang J, Black RA, Baumann G \& Frank SJ. Tumor necrosis factor-alpha converting enzyme (TACE) is a growth hormone binding protein (GHBP) sheddase: the metalloprotease TACE/ ADAM-17 is critical for (PMA-induced) GH receptor proteolysis and GHBP generation. Endocrinology $20001414342-4348$.

9 Takagi K, Saito Y \& Sawada J. Proteasome inhibitor enhances growth hormone-binding protein release. Molecular and Cellular Endocrinology $2001 \mathbf{1 8 2} 157-163$.

10 Urbanek M, MacLeod JN, Cooke NE \& Liebhaber SA. Expression of a human growth hormone (hGH) receptor isoform is predicted by tissue-specific alternative splicing of exon 3 of the hGH receptor gene transcript. Molecular Endocrinology $19926279-287$.

11 Sobrier ML, Duquesnoy P, Duriez B, Amselem S \& Goossens M. Expression and binding properties of two isoforms of the human growth hormone receptor. FEBS Letters 1993319 16-20.

12 Zogopoulos G, Figueiredo R, Jenab A, Ali Z, Lefebvre Y \& Goodyer CG. Expression of exon 3-retaining and -deleted human growth hormone receptor messenger ribonucleic acid isoforms during development. Journal of Clinical Endocrinology and Metabolism $199681775-782$.

13 Barnard R, Southard JN, Edens A \& Talamantes F. Growth hormone receptor and growth hormone-binding protein messages in mouse placenta contain the exon analogous to human exon 3. Endocrinology 1993133 1474-1477.

14 Wickelgren RB, Landin KL, Ohlsson C \& Carlsson LM. Expression of exon 3-retaining and exon 3-excluding isoforms of the human growth hormone-receptor is regulated in an interindividual, rather than a tissue-specific, manner. Journal of Clinical Endocrinology and Metabolism $1995 \mathbf{8 0} 2154-2157$.

15 Pantel J, Machinis K, Sobrier ML, Duquesnoy P, Goossens M \& Amselem S. Species-specific alternative splice mimicry at the growth hormone receptor locus revealed by the lineage of retroelements during primate evolution. Journal of Biological Chemistry $200027518664-18669$.
16 Stallings-Mann ML, Ludwiczak RL, Klinger KW \& Rottman F. Alternative splicing of exon 3 of the human growth hormone receptor is the result of an unusual genetic polymorphism. PNAS 199693 12394-12399.

17 Clark RG, Mortensen DL, Carlsson LM, Spencer SA, McKay P, Mulkerrin M et al. Recombinant human growth hormone (GH)binding protein enhances the growth-promoting activity of human GH in the rat. Endocrinology $19961374308-4315$.

18 Baumann G. Growth hormone-binding proteins. Proceedings of the Society for Experimental Biology and Medicine $1993202392-400$.

19 Urbanek M, Russell JE, Cooke NE \& Liebhaber SA. Functional characterization of the alternatively spliced, placental human growth hormone receptor. Journal of Biological Chemistry 1993 268 19025-19032.

20 Esposito N, Paterlini P, Kelly PA, Postel-Vinay MC \& Finidori J Expression of two isoforms of the human growth hormone receptor in normal liver and hepatocarcinoma. Molecular and Cellular Endocrinology 1994103 13-20.

21 Edens A \& Talamantes F. Alternative processing of growth hormone receptor transcripts. Endocrine Reviews $199819559-582$

22 Conte F, Fernandez L, Molinas C, Bieth E \& Tauber M. Functional characterization of exon 3 deleted isoform of the growth hormone receptor. Pediatric Research 200149 (Suppl) 33A.

23 Kratzsch J, Wu Z, Kiess W, Dehmel B, Bosse-Henck A, Reuter W et al. The exon 3-retaining and the exon 3-deleted forms of the growth hormone-binding protein (GHBP) in human serum are regulated differently. Clinical Endocrinology 2001 54 61-68.

24 Beguinot F, Haring H, Kiess W, Klein H, Sesti G, Smith U et al. The Search for NIDDM genes project: a European Community programme aimed to facilitate the identification of NIDDM genes. Diabetologia 199841 (Suppl) 15-16.

25 Path G, Bornstein SR, Ehrhart-Bornstein M \& Scherbaum WA. Interleukin-6 and the interleukin- 6 receptor in the human adrenal gland: expression and effects on steroidogenesis. Journal of Clinical Endocrinology and Metabolism 199782 2343-2349.

26 Kratzsch J, Schreiber G, Selisko T, Keller E, Pflaum CD \& Strasburger CJ. Measurement of serum exon 3-retaining growth hormone-binding protein in children and adolescents by radioimmunoassay. Hormone Research $1997 \mathbf{4 8} 252-257$.

27 Stern C. The Hardy-Weinberg law. Science 194397 137-138.

28 Kratzsch J, Selisko T \& Birkenmeier G. Identification of transformed alpha 2-macroglobulin as a growth hormone-binding protein in human blood. Journal of Clinical Endocrinology and Metabolism $1995 \mathbf{8 0} 585-590$.

29 Moller S, Fisker S, Becker U \& Henriksen JH. A comparison of circulating and regional growth hormone-binding protein in cirrhosis. Metabolism 200150 1340-1345.

30 Fisker S, Kristensen K, Rosenfalck AM, Pedersen SB, Ebdrup L, Richelsen B et al. Gene expression of a truncated and the fulllength growth hormone $(\mathrm{GH})$ receptor in subcutaneous fat and skeletal muscle in $\mathrm{GH}$-deficient adults: impact of $\mathrm{GH}$ treatment. Journal of Clinical Endocrinology and Metabolism $2001 \mathbf{8 6}$ $792-796$.

31 Martini JF, Pezet A, Guezennec CY, Edery M, Postel-Vinay MC \& Kelly PA. Monkey growth hormone $(\mathrm{GH})$ receptor gene expression. Evidence for two mechanisms for the generation of the GH binding protein. Journal of Biological Chemistry 1997 272 18951-18958.

32 Hattori N, Saito T, Yagyu T, Jiang BH, Kitagawa K \& Inagaki C. $\mathrm{GH}, \mathrm{GH}$ receptor, GH secretagogue receptor, and ghrelin expression in human T cells, B cells, and neutrophils. Journal of Clinical Endocrinology and Metabolism 200186 4284-4291.

Received 12 July 2002

Accepted 21 November 2002 